The Geneva Papers on Risk and Insurance, 20 (No. 74, January 1995) 57-73

\title{
Insurance Services in the Uruguay Round Services Negotiations: An Overview and Assessment of the Final Agreement
}

\author{
by R. Brian Woodrow*
}

\section{Introduction}

On April 15, 1994 in Marrakesh, most of the world's trade and/or foreign ministers from some 120 countries in all though nevertheless absent China, Russia, other countries in transition to a market economy and some of the least developed countries - queued up to sign on behalf of their respective governments the Final Act Embodying Results of the Uruguay Round of Multilateral Trade Negotiations. ${ }^{1}$ After seven long years of negotiation and failed attempts to conclude the negotiation during the previous three years, the deed had finally been done. Described by the GATT Director-General Peter Sutherland as "the most comprehensive and ambitious trade negotiation ever", the successful conclusion of the Uruguay Round and specifically the inclusion of a General Agreement on Trade in Services (GATS) is indeed an important economic and political event.

Assuming that the various elements of the Final Act are ratified and implemented in national legislation by signatory countries, ${ }^{2}$ the GATS will come into effect on January 1 , 1995. GATS will take its place as one of the three major agreements for which the new World Trade Organization will be responsible, along with the existing GATT for trade in goods (now extended to include agriculture, textiles and certain other difficult issues) as well as the new agreement on Trade-Related Aspects of Intellectual Property Rights

* University of Guelph, Canada \& ASEC, Geneva. An earlier version of a paper was presented at the Second CESAR Conference on Insurance in International and European Economic Evolution, Venice, Italy, October 14-16, 1993.

1 This is the official title of the overall Uruguay Round agreement. The various texts and decisions which comprise the Final Act together are more than 500 pages long and, with all tariff schedules and related materials, runs to over 20,000 pages. The General Agreement on Trade in Services - the subject of discussion here - is but one text within that Final Act which, with all national schedules included, will be more than 2000 pages in total.

2 This assumption should not be facilely made. In the United States, Senate debate on the Uruguay Round Final Act promises to be difficult and dangerous, perhaps similar to the 1993 vote on the North American Free Trade Agreement, and successful ratification before the end of 1994 cannot be assured. Moreover, ratification may be difficult in other countries which are crucial to the implementation of the agreement such as Japan, India and Brazil, although the possibility of a French veto within the European Community on accession to the Final Act seems to have been averted. 
(TRIPs). For the first time, trade in services - which constitute more than $20 \%$ of all world trade and is its fastest-growing component and whose importance in the domestic economies of developed countries ranges from $50-70 \%$ in terms of GDP and employment ${ }^{3}-$ will be brought explicitly under multilateral trade disciplines with established principles and rules for trade in services and an agreed mechanism for collective decision-making and dispute settlement.

The role of insurance services in the Uruguay Round trade negotiations and the implications which the Final Act will have for future evolution of the insurance industry both in Europe and worldwide are important and timely topics for examination. The present paper seeks to provide an overview and assessment of the GATS, specifically as it applies to trade in insurance services. The overall conclusion that will be drawn is a mixed one: satisfaction that insurance services are now covered under a multilateral services trade regime, disappointment that the initial commitments on insurance services made thus far by signatory countries are not more extensive and far-reaching, and resignation to the fact that the further negotiations on financial services until 1986, as mandated under the Final Act, will be critical both for the world insurance industry and the future of services trade liberalisation.

\section{An overview of the GATS, its structure and its achievements}

As is well known, the Uruguay Round trade negotiations were initiated at Punta del Este late in 1986. At that time, a Group of Negotiations on Services (GNS) was established to develop principles, rules and practices for trade in services, responding in large part to pressures from the United States government and international business and user groups ${ }^{4}$ Because of concerns on the part of many of the less developed countries, however, the GNS was established in such a way as to operate separately from though still an integral part of the overall Uruguay Round. From the outset of the negotiation, the objective was to achieve an eventual agreement on principles, rules, arrangements and initial commitments on trade in services - a General Agreement on Trade in Services or GATS - which would be mutually agreeable to a large number of signatories, including both developed and developing countries.

Insurance, as part of financial services, has always been viewed as an important sector within the Uruguay Round multilateral services trade negotiations. While many developed and some developing countries have been pursuing domestic liberalisation in all or some financial services sectors, this has not typically included effective market access liberalisation for foreign suppliers of such services. Virtually all the world's countries continue to maintain various domestic regulatory measures which penalize potential foreign services suppliers to the benefit of domestic suppliers of the same services. With regard to international insurance services specifically, one recent report has calculated that 26 countries currently deny foreign insurance companies a license to operate, another 30 or so mandate that all or a portion of ceded reinsurance be placed with a state-owned or controlled reinsurance company, and 60 other countries provide international insurers with limited acces

3 For a discussion of the current and growing importance of trade in services both in developed and in developing countries, see GATT, International Trade, 1990-91, Part II.

${ }^{4}$ On the role of US government and international business in the trade in services issue, see Geza Feketekuty, International Trade in Services: An Overview and Blueprint for Negotiations, (Cambridge, Mass: Ballinger, 1988), Appendix II. 
to their markets by restricting licenses granted to only a few classes of business. ${ }^{5}$ The identification, scheduling and eventual elimination of those barriers to trade is one appropriate task of multilateral services trade liberalisation.

The GATS which finally emerged can itself best be described as having THREE component parts integral to that agreement itself while at the same time a FOURTH component contributes to the overall architecture of the Uruguay Round multilateral trade agreement. The initial three component of the GATS are :

FIRST, a comprehensive FRAMEWORK OF PRINCIPLES AND RULES operating on two levels : the first level includes general obligations including MFN Treatment, Transparency, Domestic Regulation, Exclusive Service Providers, etc. and apply universally to all trade in services actitivities by all signatory participants; as well, a second level of principles, rules and scheduling arrangements relating specifically to Market Access and National Treatment apply once countries have made initial commitments and bound their domestic regulatory regimes relating to any particular sector or activity;

SECOND, a series of SECTORAL ANNEXES AND OTHER UNDERTAKINGS annexes on telecommunications services, financial services, temporary movement, and air transport as well further undertakings on financial and certain other services sectors - all of which tailor and extend application of the framework principles and rules to that particular sector or serve as initiatives towards further efforts at liberalisation within the particular sector;

THIRD, NATIONAL SCHEDULES OF INITIAL COMMITMENTS ON MARKET ACCESS AND NATIONAL TREATMENT across a range of different services sectors where each participating country agrees to make bindings ${ }^{6}$ of continued liberal treatment within its own National Schedule and which all other participating countries ultimately accept as sufficient for entry into force of the Final Act.

An important FOURTH component - NEW INSTITUTIONAL ARRANGEMENTS FOR TRADE IN SERVICES AS WELL AS OTHER AREAS OF WORLD TRADE has also been put in place which will locate the GATS agreement within the structure of a new World Trade Organization (WTO), establish coherent and integrated procedures for dispute settlement and further liberalization with regard to services trade, and provide for ongoing relations with other international organizations and development of new trade issues.

It must be remembered, however, that the GATS is still very much a work-in-progress, not yet a finished tapestry. Much has been accomplished in establishing a general framework of principles and rules and bringing the wide range of services sectors within its scope and coverage. All traded services are covered at least nominally under the GATS ${ }^{7}$ and the

${ }^{5}$ Cited by Henry Parker, Chairman of American Insurance Association's International Insurance Council in John Jennings \& Steven Brostoff, "GATT Gives U.S. Insurers Leverage", National Underwriter, December 20, 1993, pp. 1-25.

6 "Bindings" is of course the trade terminology for a country's willingness to guarantee particular domestic liberalisation measures or conditions either immediately upon coming into force of the Final Act or at some point in future.

7 The principle of universal coverage of all traded services and the notion of "modes of delivery" is set out in Article 1 where "services" are specified to include "any service in any sector except services 
various "modes of delivery" are set out whereby services can be traded in foreign countries - cross-border including over telecommunications links, movement of consumers as happens in the case of international travel and tourism, through commercial presence when companies establish branches or affiliates, and through temporary movement of natural persons who deliver the service. The framework of principles and rules itself is a considerable achievement, interpreting conventional goods trade principles such as MFN Treatment,${ }^{8}$ Market Access ${ }^{9}$ and National Treatment ${ }^{10}$ into the much more difficult realm of

supplied in the exercise of governmental authority" and "trade in services" is defined in terms of the four possible modes whereby any particular service might be supplied within a member country. Member countries are then obligated to ensure that all "measures by Members", including those of "central, regional of local governments and authorities" and "non-governmental bodies in the exercise of powers delegated by central, regional or local governments or authorities", conform with GATS principles and rules as well as with commitments made by that member state.

8 This fundamental principle of multilateral trade agreements, to be applied here to all trade in services, requires that "each Member shall accord immediately and unconditionally to services and service suppliers of any Member, treatment no less favourable than it accords to like services and services suppliers of any other country" (Article II [1]). If a country wishes to maintain a measure inconsistent with MFN Treatment, it may do so but must list any such measure as an Article II Exemption in its National Schedule. These exemptions would then presumably be subject to negotiation during subsequent bilateral or multilateral negotiations.

${ }_{9}$ Market Access, as set out in Article XVI, means that "each Member shall accord services and services suppliers of other Members treatment no less favourable than that provided for under the terms, limitations and conditions agreed to and specified in its schedule". In those sectors where a member undertakes specific commitments, market access by all the four modes of supply is assumed to be open, unless that member specifies in its schedule those "measures" which limit market access.

Measures which must be scheduled include the following:

a) limitations on the number of service suppliers whether in the form of numerical quotas, monopolies, exclusive service suppliers or the requirements of an economic means test ;

b) limitations on the total value of services transactions or assets in the form of numerical quotas or the requirement of an economic means test ;

c) limitations on the total number of service operations or on the total quantity of service output expressed in terms of designated numerical units in the form of quotas or the requirement of an economic needs test ;

d) limitations on the total number of natural persons that may be employed in a particular service sector or that a service supplier may employ and who are necessary for, and directly related to, the supply of a specific service in the form of numerical quotas or the requirement of an economic needs test;

e) measures which restrict or require specific types of legal entity or joint venture through which a service supplier may provide a service; and

f) limitations on the participation of foreign capital in terms of maximum percentage limit on foreign shareholding or the total value of individual or aggregate foreign investment. (Article XVII[2]).

Where a member undertaking a specific commitment "maintains or adopts" such measures as part of it domestic regulation, these must be listed in its National Schedule as limitations on Market Access which should, over time, be negotiated away.

${ }_{10}$ National Treatment, as set out in Article XVII, then follows from whatever Market Access commitments a member has chosen to list in its National Schedule. For those sectors and subject to listed conditions and qualifications, "each Member shall accord to services and services suppliers of any other Member, in respect of all measures affecting the supply of services, treatment no less favourable than that it accords to its own like services and services suppliers". Further, the National Treatment standard can be met by extending "either formally identical treatment or formally different treatment", as 
services where stubbornly-held domestic regulatory practices rather than tariffs constituted the primary barriers to international trade.

Likewise, some of the sectoral annexes - though unfortunately not those in financial services as will be demonstrated later - constitute useful elaborations of the framework to particular services sectors which are at the core of the evolving services economy. "For example, annexes on telecommunications where "access to and use of" the basic network and services is dealt with and air transport where multilateral liberalisation of "soft services" such as ground services or computer reservation systems is hived off from "hard services" like landing rights which remain subject to bilateral arrangements provide good starting points for further liberalisation. The framework and annexes have, arguably, their own particular strengths and weaknesses but these will only become readily apparent as the GATS is implemented and as individual countries and companies engaged in international business operate within its disciplines.

When all is said and done, however, it is the range and level of liberalization commitments which countries were willing or unwilling to undertake that tells the tale. In this regard, the GATS must be judged disappointing and especially so in the area of financial services including insurance. As a broad generalization, the more than 80 countries $^{12}$ required to submit National Schedules under the GATS as a condition for signing the Final Act in Marrakesh tended to be rather cautious, making binding commitments in already relatively open services sectors such as business services, distribution services, tourism, value-added telecommunications, many professional services, services auxiliary to transportation, but only certain limited aspects of banking, insurance and not others. On cursory observation, one positive point to note about the commitments made is the extent to which countries have been willing to commit on Market Access and National Treatment relating to commercial presence, i.e. more open investment rules, even though they have been less willing to bind on cross-border or other modes of delivery. A full assessment of what's in, what's out and what it all means must await detailed examination of the 2000 pages of National Schedules appended to the GATS, which is in turn part of the more than 20,000 pages of the Final Act.

Moreover, it was particularly disappointing that, in the final hours of the negotiation last December, several last-minute compromises and process ${ }^{13}$ decisions had to be taken in order to conclude the Round. The most critical of the process decisions was to defer any

appropriate, to that of domestic services and suppliers so that the "conditions of competition" are no less favourable.

1 Sectoral Annexes were the focus of extensive and intensive activity within the GNS from mid1989 until the end of 1992 . The rationale for an annex was that the special characteristics of a particular services sector might need to be recognized in the application of framework principles and rules. Sectoral experts in different countries and in various services sectors then became directly involved in determining whether a sectoral annex might be necessary and how it might operate. This greatly complicated the GNS negotiations and brought new actors and interests into the negotiation.

12 The least-developed countries were granted one additional year, i.e. until April 15, 1995, to submit their National Schedule in conformity with the Final Act. It is expected that 30 or so countries will fit within this category.

13 These are described as process decisions because they grew directly out of the December 15th deadline for completion of the Uruguay Round and represented attempts agreed to by all countries to find ways around impasses on particular sectors or issues which might have scuttled important elements of a comprehensive GATS agreement. 
final outcome on financial services until six months after the entry into force of the GATS in order to attempt to allow extra time to sort out the disarray among major countries on this issue and to strengthen and deepen initial commitments (especially from Japan and other Asian and Latin American countries). ${ }^{14}$ In addition, other process decisions were also taken to undertake further negotiations which are not scheduled to conclude until 1996 in the areas of basic telecommunications ${ }^{15}$ and possible initial commitments on maritime services. ${ }^{16}$ In these areas as well as in others such as on specification of temporary movement of natural persons where further work is to continue into 1995 and on professional services where a working party on implementation was established to deal with licensing and standards first in the field of accountancy, the GATS remains very much a work-in-progress. And finally, on the sensitive subject of audiovisual services which contrary to some reports is a covered service under the GATS, the major protagonists - the United States and the European Community - decided for the time being to "agree to disagree" about philosophies and commitments, though no doubt to continue to fight out their battles on other grounds in the coming years. ${ }^{17}$

\section{What happened to financial services and insurance?}

Financial services - including banking and securities as well as insurance - was described earlier on in the Round by one prominent participant as potentially "the Achiles Heel of the Uruguay Round negotiations". ${ }^{18}$ In the final days of the negotiations in Geneva, it came very close to being just that. Trade liberalisation across borders in the financial services field has been very much a priority for some countries - the United States and the

14 The details are set out in the Second Annex on Financial Services as well as a further Decision on Financial Services. This rather clumsy arrangement became necessary in the final days prior to December 15, 1993 when it became clear the quality of offers, withdrawals of offers and threatened exemptions would effectively gut the application of the GATS to financial services. Countries were given up to 6 months after the entry into force of Final Act to register derogations from MFN Treatment or "improve, modify or withdraw" their existing commitments on financial services. All countries seem to have agreed to leave their existing offers on the table and to allow this extension of the period as their "second-worst alternative". For further discussion, see subsequent section of this paper.

15 Separate from the Annex on Telecommunications, a large number of countries included valueadded telecommunications within their National Schedule but it had been agreed more than a year previous that a further negotiation specifically on basic telecommunications services should be undertaken with a view to the eventual inclusion of country commitments in this area.

16 An Annex plus a Decision on Maritime Transport Services likewise sets out a two-year process for negotiations on "international shipping, auxiliary services and access and use of port facilities", though no mention is specifically made of the delicate issue of cabotage. This process decision became necessary when it became clear that the US and EC could not resolve their differences and was also a "second-best alternative" to total exclusion from the GATS.

17 After slow progress had been made during the last two months on resolving difference on several key elements of the audio-visual issue, it became clear in the final couple of days that a US-EC deal could not be done. Thus, no annex of audio-visual services was included, the US left its thoroughly liberal conditional offer on the table, and the EC made no commitments although neither did it take an MFN exemption on audio-visual services.

18 This was the term used by Joan Spero, then a senior executive at American Express, to describe the crucial role of financial services within the services negotians and the Uruguay Round. By the end of the Round, Ms. Spero was a senior US Treasury official closely involved in the final negotiations. The initial comment was made at a Royal Institute of International Affairs conference held in London in January 1990. 
European Community and their aggressive multinational banks and insurance companies for example - but just as persistently resisted by others such as Japan and many other Asian and developing countries. Exactly how much liberalisation could be achieved during the Uruguay Round and through what mechanisms was a central concerns throughout the GNS negotiations. As well, difficult structural issues related to the continuing scope for prudential regulation, treatment of cross-border trade by modes other than establishment, and the volatility of global financial markets had to be considered and resolved. What evolved out of this mixture of complex issues and divided purposes was a muddled, contradictory and ineffective set of financial services disciplines and commitments which could not ultimately be supported.

Early on in the negotiation during 1989 , it was decided that insurance should be treated along with banking and securities because of the similarity of the issues raised and that the specificities of each could be dealt with in a possible sectoral annex on financial services. ${ }^{19}$ A Working Group of Financial Services was established and the possibility of a financial services annex to the GATS quickly became a major source of conflict. It was no secret that most of the world's finance ministries and central banks would have preferred that financial services not be treated within a multilateral trade agreement at all. Country trade negotiators in Geneva, however, knew that financial services had to be included in any services trade agreement in order that coverage be complete and were thus prepared to see a generous "prudential carve-out" 20 but were agreed on little else that should be included in the annex. Japan and many Asian countries wanted nothing in the framework or annex which might interfere with or give direct access to their strong domestic financial markets which have been so crucial to their growth and development. And many developing countries also feared that financial services trade liberalization was merely a cover for the large global services companies to move more extensively into their national economies. In this regard, the main contention over the financial services annex related primarily to banking rather than insurance, but the latter tended to get drawn in. By the time of the Brussels

${ }^{19}$ This amalgamation of insurance with banking and securities is certainly the now conventional approach. Note, however, that the Canada-United States Free Trade Agreement which came into effect in 1989 includes insurance along with other services sectors and contains a separate chapter which treats financial services. As to the specification of what constitutes a "financial service", the Financial Services Committee of the Coalition of Services Industries in the US developed an extensive listing of specific financial services and the Annex more or less followed this approach. "Insurance and insurance-related services" were categorized separately from "banking and other financial services (excluding insurance)" as

(a) Direct Insurance (including co-insurance):

(i) life

(ii) non-life

(b) Reinsurance and retrocession;

(c) Insurance intermediation, such as brokerage and agency;

(d) Services auxiliary to insurance, such as consultancy, actuarial, risk assessment and claim settlement services.

20 "Prudential carve-out" was the term given to what was to become Article 2.1 of the Financial Services Annex to GATS which stated that " $(\mathrm{N})$ otwithstanding any other provisions of the Agreement, a Member shall not be prevented from taking measures for prudential reasons, including for the protection of investors, depositors, policy holders or persons to whom a fiduciary duty is owned by a financial serviccs supplier, or to ensure the integrity and stability of the financial system". 
ministerial meeting in December 1990, which was originally intended to end the Round, no agreement could be reached either on the role or the content of a financial services annex. ${ }^{21}$

During 1991, attention focused on the so-called "two-track" approach to financial services. ${ }^{22}$ In addition to a Financial Services Annex which would include little more than a listing of financial services to be covered and the broad "prudential carve-out" to deal with domestic regulatory activities, a second instrument might be developed which would set out a plan and process for more extensive liberalization within the sector and which would apply only to those countries which explicitly agreed to accept those disciplines. This latter initiative became the Understanding on Commitments in Financial Services which set out a higher level of minimum obligations which countries would voluntarily accept and an alternative method for scheduling so as to lock in commitments among those countries expected to follow it, primarily the OECD countries although a few others might also subscribe. For insurance services, this would mean that countries could offer more inclusive sets of initial commitments and bind broader liberalization within the sub-sector or specific activities. When a consensus final agreement among Uruguay Round negotiators proved impossible by the fall of 1991 and the GATT Director-General issued his "Dunkel Draft" of a Final Agreement in December 1991, both the Financial Services Annex and the Understanding on Commitments in Financial Services were included.

Between 1991 and 1993, the "hard bargaining" really began through an offer/request/ exemption process ${ }^{23}$ whereby the initial commitments to be undertaken by all signatories to the eventual agreement were registered. It was that process which could not be completed fully and satisfactorily by December 15, 1993 when the Uruguay Round was brought to a conclusion. Successive waves of conditional country offers were exchanged among all GNS participants and these were often followed up by bilateral contacts and/or written requests

21 What eventually was included in the Brussels package of draft agreements was a single blank page with only the title at the top. This was to signify that an annex was necessary but countries could not agree on the form or content of that annex. At that Brussels meeting in December 1990, two country submissions were made - one by a group of four developed countries and the other by the South East Asian countries - which restarted the process of developing in Financial Services Annex.

22 The "two-track approach" as it evolved during late 1990 and 1991 was advocated by the United States as a way of separating those countries which might be willing to assume higher levels of commitment to liberalization from those which would not. For countries in the former category, a separate text would set out the substance and mechanism for those commitments which would apply only among those countries. This proposal grew out of the continuing US concern about granting MFN Treatment to countries which would take no serious liberalization initiatives of their own but could act as "free riders".

${ }^{23}$ The offer/request/exemption process came to work more or less as follows : to be "in the game", a country must submit a conditional offer on Market Access and National Treatment for at least one services sector or activity which would apply to all potential trading partners through MFN treatment ; such an offer would specify those particular sectors or activities where the country would be prepared or not to bind existing degrees of liberalization according to one or more modes of delivery for that service or activity; trading partners could then respond to that offer by exploring its substance and implications through bilateral contacts and/or submitting requests for clarification of detail or for consideration of possible improvements when revised offers were made; at any time in the process right up to its conclusion, a country could indicate its intention to seek an exemption from MFN Treatment for any particular sector or activity if the country felt that it could not open a sector or activity to full MFN treatment or if it was not satisfied with the range or depth of initial commitments being offered by other countries. 
submitted to particular trading partners. Through numerous iterations, it gradually became clearer what a particular country was willing to offer on insurance services or any other sector or activity. ${ }^{24}$ However, during the last three months of the negotiations, the scheduling process whereby these conditional offers would be transformed into binding National Schcdules was complicated even further in the financial services area. The large majority of countries used the "bottom up" scheduling method set out in the framework whereby a country advanced only those activities where it wished to make at least some liberalisation binding while only the OECD countries followed the alternative scheduling method set out in the Understanding on Commitments and took the "top-down" approach of binding wholc sectors or sub-sectors and then making specific limitations on market access and national treatment in their National Schedules. ${ }^{25}$ Countries which felt that they could not extend full and open MFN Treatment to all trading partners could also register an Article II excmption ${ }^{26}$ and these became increasingly popular in the financial services area as the Uruguay Round moved towards its conclusion.

As of early September 1993, more than 60 negotiating parties, with the EC representing its 12 members, had submitted conditional offers. The stated aim of negotiators was to achieve a "big basket" of initial commitments rather than to allow minor difficulties to result in deletion or watering down of commitments in sensitive sectors. With regard to insurance, roughly 50 of the participants are offering initial commitments under the framework or the understanding in one or more sub-sectors of insurance. Virtually all countries have listed reinsurance and retrocession and, in effect recognizing its de facto status as an internationalized industry, were prepared to bind market access and national treatment both through establishment and cross-border provision. Some developed countries, especially in Western Europe and North America, were probably prepared to make more extensive offers especially in the area of non-life insurance. ${ }^{27}$ Because of its close relationship to domestic national economies, however, most countries chose not to offer market access

\footnotetext{
${ }^{24}$ For example, Country A might commit itself to maintain no limitations on market access or national treatment for non-life insurance offered both through establishment and cross-border modes of delivery while Country B might not allow cross-border provision but offer unrestricted market access for reinsurance and retrocession or Country $\mathrm{C}$ might retain certain specific national restrictions on retention of life insurance premiums within the country.

25 The "bottom-up" versus "top-down" approaches to scheduling seemed to serve the different interests of the countries concerned. An LDC could make a positive offer of market access/national treatment in discrete activities and at the same time guard insurance services in other areas. Those using the "top-down" approach had to commit to broader areas of market/access and then, on a negative basis, list any limiting measures in domestic insurance regulation. This fundamental difference in scheduling approach makes it extremely difficult to analyze the National Schedules to the GATS, especially as some OECD countries and even the US did not always follow the "top-down" approach in all of its bindings.

${ }^{26}$ Exemptions to Article II indicate that a country cannot accept full MFN Treatment in a particular sector of sub-sector and, in effect, takes unilateral action to pull that item "off the table". These were supposed to be taken only infrequently and in extreme cases where a country simply could not accept application of the GATS in a specific area. MFN exemptions seriously undermine the comprehensiveness of the overall agreement and its value to other trading partners.

27 The US offer included both life and non-life insurance together but listed a wide range of statelevel restrictions on cross-border and establishment provision of these services; Japan at this point in the negotiation registered their limitations on market access and national treatment by mode of delivery rather than by sector or sub-sector and was able to shield its continuing protection of direct
} 
and national treatment for life insurance. Although the overall set of country offers on financial services did not go all that far towards liberalization, most participants, including the US, felt that these could and should be "harvested" even if further improvements could not be achieved.

Over those last three months, however, the GATS negotiations on financial services became a particularly curious game, taking on something of an "Alice in Wonderland quality". Attention focused primarily on the bilateral talks between US Trade Representative Mickey Kantor and his EC counterpart Sir Leon Brittan who met roughly every two weeks throughout this period either in Brussels or Washington. In Geneva among the broader range of GNS participants and in contacts among officials in respective capitals, everyone involved in services busied themselves with readying their national schedules and waited in anticipation of "the breakthrough" - the broad interlinked one involving services, agriculture and other contentious issues or even a much narrower one on financial services specifically - either of which would bring the US and EC positions into alignment on financial services. No country was more in anticipation than Japan which knew that "the breakthrough" would bring in its wake acute pressures to significantly upgrade its conditional offer on financial services and other Asian and Latin American countries would then be placed under similar pressure. Likewise, the private sector proponents of a strong financial services sub-agreement both in the US and key European countries, which had tended to lose interest in the GATS as deadline after deadline was not met, were once again mobilised to press the case through to a conclusion. ${ }^{28}$

All was in readiness for "the breakthrough" but nothing much of substance ever happened during October and November. For whatever reasons, the US decided internally ${ }^{29}$ to focus once again on its MFN Treatment concerns and to put forward the issue of a possible "two-tier" final agreement in the financial services area - not to be confused with although implicitly related to the earlier "two-track" strategy on initial commitments. Under the US proposal, GNS signatories would be divided into two camps, one group which were willing to meet a range of liberalization thresholds among whom unconditional MFN Treatment would apply and a second group which would be offered conditional MFN treatment until they could bring their domestic regulatory regimes into line. With the EC standing on the sidelines for the moment, the US raised the issue of a possible "two-tier" agreement at a GNS meeting in mid-October. The proposal was rejected outright by virtually all other GNS participants and went nowhere. Not surprisingly, it draw a strong negative response

insurance markets; several EC countries including the United Kingdom, Germany and the Netherlands would have been prepared to offer greater market access in direct insurance but the EC was precluded from doing so by the more protectionist views of other member-states. For further information on these country positions, see subsequent section.

${ }^{28}$ For example there was growing interest and support within the European insurance industry and national industry associations and some individual companies even in countries like France pressed their trade officials to get an outcome in the insurance area.

${ }^{29}$ The continuing division between the Office of the US Trade Representative, which was responsible for conducting the negotiation, and various arms of the Department of the Treasury which actually took charge of certain aspects of the financial services negotiations cannot be dealt with here in any detail but was a major reason behind the lack of focus in the US position towards the end of the negotiation. 
from Japan and other Asian countries who saw themselves as the primary target as well as from the LDCs who regarded it purely as "power politics" which required a response in kind. ${ }^{30}$ In addition, the US also raised other issues or ones which had seemingly been resolved. Tax treatment of international services suppliers was such an issue. US Treasury officials sought and largely got their way in terms of the wording of a large "tax carve-out" which would ensure that countries could effectively impose and collect direct taxes from foreign suppliers. ${ }^{31}$ What never happened during those closing months and weeks was any determined effort to engage Japan, other Asian and Latin American countries, and LDCs generally in a process of upgrading initial commitments on market access and national treatment in financial services. Instead, Japan actually moved slightly to downgrade its financial services offer ${ }^{32}$ and several other Asian, Latin American and developing countries either pulled offers off the table or threatened to do so. The obvious danger was that all would be lost in financial services in a last spasm of exemptions and withdrawals.

During the last few days and even the last few hours of the negotiations, financial services was at the top of the list of outstanding issues which had to be resolved if the Uruguay Round was to be concluded. At the crucial meetings convened by the GATT DirectorGeneral on financial services, the US took the position that the range and quality of country offers, especially from Japan and Asian countries, was simply not good enough to allow then to accept unconditional MFN Treatment within a multilateral context and, on December 14th, even threatened that it would be willing to leave financial services out of the final agreement altogether. ${ }^{33}$ The EC agreed substantially with the US analysis on initial commitments but definitely did not want to see financial services absent from what would then have become a much weakened, piecemeal and rather toothless GATS. Japan for its part however much it did not want a strong financial services discipline - also did not want to be painted by its trading partners as the cause, though this was hardly in fact the case, for total elimination of financial services from GATS or even in the worst scenario for failure to conclude the Uruguay Round. It was this very real possibility that loomed over the negotiations as they moved towards the December 15th deadline for their conclusion.

${ }^{30}$ Countries like India, for example, which had at their outset opposed the whole of the services negotiations but which later played a much more constructive role, threatened to withdraw their offer on financial services. Even though the Indian offer on insurance services did not go so far as to give up existing domestic oligopoly control over life insurance, it did point in the direction of useful regulatory reform. Losing such an offer would have both symbolic and substantive costs.

3! A great deal of time was spent during October and November dealing with US concerns on this issue. The outcome was the development of an extensive footnote to Article XIV on exceptions which detailed the wide variety of measures which a country could take to ensure the "effective" imposition and collection of direct taxes on international services activities.

32 Japanese unwillingness at the time to move on market access and national treatment in financial services is partly explained by the weak coalition government which came into power in July 1993 as well as by its preoccupation with the highly symbolic issue of lifting the ban on imported rice. As well, of course, Japanese banks and insurance companies were strongly opposed to any significant opening of Japanese financial market to enhanced foreign competition.

${ }^{33}$ One of the implications of leaving financial services out of the GATS entirely would be that the US and other countries would then be free to pursue liberalization through bilateral and other means. If it remained within GATS, the overriding obligation of signatory countries to follow multilateral mechanism for dispute resolution would be preserved. 
At this decisive point, GATT Director-General Peter Sutherland ${ }^{34}$ intervened to press a process solution whereby the GATS would go forward for signature and ratification by countries while negotiations on financial services would be extended over a two-year period subject to certain conditions such as interim MFN Treatment, a standstill on countries taking any further restrictive measures, and that countries leave their last conditional offers "on the table" for extended negotiation. The Director-General's Uruguay Round team, GNS officials and country representatives worked through the early hours of December 15th in Geneva fashioning two last-minute additions to the GATS. A Decision on Financial Services was quickly drafted and added to the Final Act which reaffirms that financial services commitments, as negotiated to that point, would enter into force on an MFN Treatment basis at the same time as the GATS itself and countries seeking exemptions from MFN Treatment would suspend their application until 6 months after GATS is operating. In addition, a Second Annex on Financial Services was also added which allows countries to retain the right to seek an MFN Treatment exemption until 6 months after GATS comes into force but also ensures their right prior to the end of that 6 months to "improve, modify or withdraw all or part of their commitments on Financial Services inscribed in its schedule" ${ }^{35}$ In other words, the outcome was that the financial services aspects of the GNS negotiation were to be extended for another two years in order to give more time to improve the outcome on initial commitments, even though the GATS itself will go into effect as scheduled.

\section{The evolving positions taken by the United States, European community and Japan on insurance services}

Before concluding by looking specifically at the implications of the GATS for the world insurance industry, it is useful to profile the positions of the US, EC and Japan on insurance services as these positions have evolved over the course of the Uruguay Round. This is especialy important in light of the extension of negotiations until 1996 since these positions become the effective starting point for those extended negotiations. The essential positions of the three major players on financial services and especially insurance can be known by their statements and actions and a summary analysis of the offers, request and exemptions which each has made as part of the ongoing initial commitments exercise. ${ }^{36}$

${ }^{34}$ This is only one instance where the institutional and personal leadership of the GATT DirectorGeneral came to the fore. The GATT Director-General has virtually no direct power of his own in dealing with individual countries involved in the negotiations and little in the way of institutional profile within the processes of international economic policy-making.

${ }^{35}$ The Decision and Second Annex brings to 8 the number of elements which must be taken into account in assessing the financial services provisions of the GATS. In addition to the Framework Agreement, the original Annex and Understanding on Commitments and the National Schedules, two other items were also included. A Decision on Institutional Arrangements for the General Agreement on Trade in Services provides for sectoral committees to be established to monitor implementation of the GATS and specifically a Committee on Financial Services which will also oversee the two years of extended negotiations. As well, another Decision on Certain Dispute Settlement Procedures for the GATS established a roster of expert panelists who would be called upon the serve on dispute settlement panels - a key concession to the world's treasuries and central banks who remained anxious about treating financial services in a multilateral trade agreement.

36 It is of course exceedingly difficult to identify with precision what constitutes the real positions of major players in the Uruguay Round such as the US, the EC, and Japan on a single issue like insurance. Statements may be made and actions taken within a negotiation which may be calculated for 
For the US, financial services has always been a potential deal-breaker and a most important feature of any Uruguay Round Final Agreement. The longstanding efforts on the part of the US government and international business first to get trade in services onto the Uruguay Round agenda and then to press sectoral trade liberalization across a range of services sectors are well known. Financial services along with telecommunications were probably the priority interests of the US government in the GATS, although it is the international banking aspects of financial services rather than insurance which have been most critical. Even on insurance, however, there is a strong US lobby for international insurance services comprising the major companies active in international insurance markets plus industry trade associations as well as services groups beyond insurance which continue to press for strong financial services provisions within the GATS. ${ }^{37}$

On trade in insurance services, the US position has been to support further internationalization of all areas of insurance, but with priority to non-life insurance, and has been particularly concerned about continuing stubborn protectionism in Asian insurance markets. ${ }^{38}$ Because of the relative liberalization which has already been achieved in its own financial services markets, there has always been the strong possibility that the US may have to maintain exemptions from MFN Treatment for certain financial services activities. The US offer on insurance on the table in Geneva would seek to open up both life and nonlife areas of insurance, while in essence consolidating existing liberalization in reinsurance and retrocession. To this end, the US remains willing to bind existing market access and national treatment both for cross-border and establishment trade in insurance services, except where certain state governments maintain limitations on licensing of foreign or government-owned insurance companies ${ }^{39}$ Further, the US would claim that there are current limitations with regard to insurance intermediation activities by foreign insurance companies ${ }^{40}$ In its dealings with the EC, Japan and other countries, the US has been pressing for similar degree of market access and national treatment and, in particular, has sought greater openess for US insurance companies in Japan and Korea. With regard to the EC specifically, the US position has been to encourage efforts by the Commission to harmonize insurance regulations across the Community, viewing this as a positive step for continued market access after completion of its internal market reforms in 1992. Subsequent to the

effect as much as to express the carefullly coordinated government position. Moreover, positions taken on one issue may be contingent on gaining favourable concessions on other issues and what result a government is finally prepared to accept in one area will depend very much on assessment of the overall package.

${ }^{37}$ Insurance industry groups and firms in the US have played a significant in pressing for a GATS covering insurance services. Firms such as American International Group and Chubb and Cigna in the United States as well as the International Insurance Council have been most aggressive while other insurance industry groups and firms in Europe and Japan have tended to be less committed.

38 Barriers to trade in insurance services has been prominent in US National Trade Barriers reports since the mid-1980's and insurance was one of four priority areas in bilateral market access talks with Japan during 1993 and 1994.

39 The GATS contains a "best endeavours" clause with regard to application of the agreement and initial commitments in federal states. However, the breadth and depth of limitations among US states is of major concern to US trading partners. See Article 1(3).

${ }^{40}$ For an assessment of the US position, see Report of the Services Policy Advisory Committee on the Result of the GATT Uruguay Round Negotiation, dated January 12, 1994. 
completion of the Uruguay Round, the US Congress began deliberations on different versions of a proposed Fair Trade in Financial Services Act which would allow the executive to pressure individual countries to eliminate restrictions on the operations of US financial services providers abroad. ${ }^{41}$

For its part, the European Community, with the Commission representing all its 12 member-states in the Uruguay Round negotiations, is also strongly supportive of the need for strong financial services provisions in the GATS. Like the US, it has been particularly interested in its banking rather than its insurance aspects and, also like the US, the Commission has become increasingly concerned about Japanese and Asian protectionism in financial services. Unlike the US, however, the EC is not pressing aggressively for further internationalization in the insurance field nor is it interested at this time in offering commitments on life and non-life insurance. The fact that the EC initially made no offer on life and non-life insurance, where internal market reforms and questions of competency and subsidiarity are still ongoing, its testimony to the importance of this constitutional process in continually shaping the EC position. ${ }^{42}$ The Community simply cannot make trade negotiation offers in Geneva on life and non-life insurance unless and until these have been elaborately prenegotiated among member-states within the Community. In addition, particularly for life and non-life insurance companies, existing reciprocity measures in Community and member-state legislation would not conform with obligations of unconditional MFN Treatment under the final agreement and would require scheduling or exemption. ${ }^{43}$ Lastly, it should be noted that European insurance companies and their national and pan-European representation have been more cautious in their support for a strong EC position on insurance services within GATS than have their US counterparts.

The EC's early offer on insurance thus related only to reinsurance and retrocession where it identifies a list of some 10 limitations on market access in different member-states, several of which have been lifted as part of the internal market reforms. With these limitations, the EC has maintained its offer to bind market access and national treatment in this area. Its more recent offers during 1993 and its National Schedule apply to all insurance and insurance-related services but also list a more substantial number of restrictions on market access and national treatment relating to life and non-life insurance in member-states, primarily in the South European countries. Maintenance of the EC's reciprocity provisions contained in relevant banking and insurance directives is also a major source of concern, both within the EC among its traditionally more protectionist member-states as well as among its major trading partners, but the EC has indicated formally that it would be prepared to "sheath" this trade weapon if stronger financial services provisions in the GATS

41 It is expected that this legislation, if and when passed, would target countries like Korea, India, Malaysia, Thailand and possibly Japan - but probably not any EC Countries.

42 The link between EC internal market reforms and their position on trade liberalization is crucial. Trade policy in the EC is framed within the Article 113 Committee in Brussels which coordinates with relevant directorates within the Commission and among member-states.

43 The EC position has been that its reciprocity clauses in the Second Banking Directive and corresponding provisions in its insurance and securities directives, like other types of unilateral action such as the US Section 301 clause in its trade legislation, is incompatible with MFN Treatment within GATS and would require an exemption from MFN Treatment. 
were to result from the extended negotiations. ${ }^{44}$ Finally, in its dealings with the other major countries relating to insurance, the EC has questioned the effective market openess of countries like the United States where state regulatory practices can and have severely limited the ability of foreign insurers to establish within their boundaries but has not taken the matter further. Likewise, the EC has also pressed Japan, though with little apparent success, to modify its restrictive practices towards foreign insurance brokers, retrocession and transport insurance.

Lastly, there is the position taken by Japan on financial services and specifically on insurance. Both the US and EC are in common agreement that the most recent Japanese offer, as represented in its National Schedule, remains inadequate. After earlier presenting their offers in a confusing format, Japan has now made what looks like a very "clean and comprehensive" offer, but which maintains a long series of limitations on market access and national treatment in virtually all areas of banking, securities and insurance. ${ }^{45}$ For example, foreign insurance companies would continue to be limited in establishing branches and subsidiaries in Japan or operating as brokers and cross-border provision of insurance services, even in the area of reinsurance, would be severely restricted. However, while not registering them specifically as Additional Commitments, the National Schedule submitted by Japan hints at further actions to be taken towards enhanced market access and national treatment in certain areas of insurance, though clearly on its own terms and at its own pace. During the last months of Uruguay Round negotiations, Japan must count itself fortunate that it was not pressed more strongly by the US and EC to improve its initial commitments but it is unlikely to escape such pressure during the extended negotiations on financial services. ${ }^{46}$

Japan has never been a major proponent of including financial services provisions in the GATS and has seen relatively little benefit for itself in further liberalization and internationalization through multilateral trade agreement in this field. Its instincts are protective if not protectionist in an area like insurance and the government is strongly supported in this position by its domestic financial services industry. Until recently at least, its domestic insurance industry has been more or less satisfied with concentrating on buoyant domestic markets but this may be changing as Japan moves more deliberately into emerging Asian markets. The irony may well be that the lure of Asian banking and insurance markets rather than direct US or EC pressures will do more to induce change in the Japanese position. Moreover, Japan is also very much concerned and committed to maintaining the stability and health of the multilateral trading system and may eventually be willing to accept further international disciplines on its actions in insurance and other financial services sectors as

44 During the first 6 months after the GATS comes into effect, now scheduled for January 1, 1995, all countries must apply full MFN Treatment. For this period, the EC reciprocity clauses will be temporarily put in limbo. After that time and in view of the state of the extended negotiations on initial commitments, countries must decide whether or not to retain such third country provisions and seek the necessary exemption. On the existing EC reciprocity clause and its future, see Ian Wilkinson, "The Uruguay Round and Financial Services", Journal of International Banking and Law, (forthcoming, 1994).

45 In earlier offers, Japan tended to list limitations on market access and national treatment against modes of delivery rather than types of insurance services. This was rectified in their National Schedule.

46 During highly publicized bilateral talks between the US and Japan during and after February 1994, market opening measures in insurance were one of four priority areas of discussion. 
the price it must pay for maintenance of a dynamic world trading system. ${ }^{47}$ For these reasons, there is at least some circumstantial reasons for optimism about modest improvements in Japan's initial commitments in financial services including insurance during the upcoming period of extended negotiations.

\section{How the GATS will affect insurers worldwide and the insurance industry}

Let me conclude by examing briefly how the GATS will likely affect insurers worldwide and the world insurance industry. The short answer is that it will probably affect them little directly and over the short term, but that the longer term impacts are likely to be more significant. As noted at the beginning of the paper, my judgment would be that the Uruguay Round produced very much a mixed result as far as financial services are concerned. Trade liberalization in a services field such as insurance must be expected to begin with modest though still significant commitments on the part of most countries but these are likely to become more extensive and deeper in future years. Not surprisingly, while it is the already substantially internationalized sub-sectors of reinsurance and retrocession, large risks and transport insurance which have received the greatest attention, the principles and rules in the framework agreement and its sectoral annex and undertakings will apply to some extent and degree to all areas of insurance, including life and non-life insurance. Moreover, all of the major developed countries and many key developing countries in Latin America and Asia-Pacific have included insurance services in some form in their initial liberalization offers.

More detailed sectoral analysis will be required to determine the real value of those commitments and to monitor what happens as the extended negotiations proceed. Obviously, the implications for individual insurers worldwide will ultimately depend upon which countries choose to bind what types of insurance services, whether or not sufficient numbers of countries make specific commitments in the sector, and how extensive are country commitments in terms of their implications for effect market access and national treatment in the various insurance sub-sectors.

In the first instance, however, a successful Uruguay Round services trade agreement will affect insurers worldwide because their national industries - as for all internationally traded services sectors - will now be covered by a new framework or principles and rules. The GATS framework sets out a number of important general obligations to be assumed by signatory countries such as non-discriminatory regulatory treatment of foreign services suppliers, transparency of national laws and regulations, and teatment of monopolies and exclusive services suppliers. As well, it allows but does not obligate countries to make specific commitments on market access and national treatment, through various modes of delivery subject to scheduled limitations, in those services sectors or sub-sectors where they wish to offer liberalized access across national borders. One point is certain: insurance services are covered under the agreement and every signatory country will be obligated at the minimum to apply the general disciplines of the agreement to its national industry.

The second important feature of the Uruguay Round services trade agreement which should be of interest to insurers worldwide relates to the Annex on Financial Services and

\footnotetext{
47 Japan - along with other countries like France, Canada, India and a few others - were perhaps the strongest supporters of the new World Trade Organization as the best way of curbing excess regionalism and unilateral trade action.
} 
the Understanding on Commitments. The Financial Services Annex is based explicitly on the notion that governments must be allowed broad scope to exercise prudential regulation over banking, insurance and securities within their national economies and not be viewed as engaging in restraints on trade in services. It also attempts to indicate an appropriate role for cross-border trade in financial services, especially over global telecommunications networks, and to provide some guidance on how countries should treat establishment of foreign financial services suppliers both through subsidiary and branch operations. The separate Understanding on Commitments in Financial Services in effect offers a faster track to services trade liberalization which only the more developed countries will likely take advantage in scheduling initial commitments. While it established a minimum standard of obligation across a variety of sensitive financial services issues, it is important to recognize that the more developed countries do not apply the understanding in a uniform way in their National schedules. It is to be hoped that some of these shortcomings can be corrected during the period of extended negotiations on financial services.

The third important feature of the Final Act for insurers grow out of the decisions taken to extend the financial services negotiations until 1996 and the dynamic - or rather the lack thereof - for those continuing negotiations. Only a recognition of the wide-ranging implications of not including financial services in the GATS and deft action in the last days and hours to set up these extended negotiations saved the day. Whatever form these extended negotiations now take, the essential problem will be to create and sustain a new dynamic for what have now become essentially sectoral negotiations in financial services. It is difficult to see why many countries will want to move off their current positions and voluntarily towards stronger initial commitments. Leverage of a different sort will be needed to move the extended negotiations along now that the interlinkages of a comprehensive trade negotiation are no longer there and the threat of unilateral trade actions have supposedly been put aside. Nevertheless, any thought of what a failure to achieve improved initial commitments by 1996 might mean is too difficult to contemplate in the justifiably euphoric days after Marrakesh. 